International Journal of Research in Engineering and Innovation
(IJREI)

\title{
Determination of trimethoprim by various analytical techniques- A- review
}

\author{
Amina M. Abass, Sahar Alabdullah, Huda ghalib Salman \\ Department of Chemistry, College of Science, Al-Nahrain University, Al-Jaderia, Baghdad-Iraq
}

\begin{abstract}
Trimethoprim is one of the representative drugs within the pharmaceutical and personal care products (PPCPs) group and one of the main pollutants in pharmaceutical wastewater, mainly used in synergistic antibacterial activities. Trimethoprim found with sulfamethoxazole combination have a synergetic effect, due to the inhibitor effect that occurs in more than one step during the obligatory sequence of enzymatic reactions in the bacteria. It is used individually in the treatment of respiratory tract infections, urinary tract infections, intestinal infections, and other diseases. Therefore, it is important to develop rapid, simple and low cost analytical methods for the simultaneous quantification of these compounds for a good quality control. A considerable number of analytical papers for determination of association in commercial formulations and biological samples have been reported in the literature, these include mainly spectrophotometric, chromatography, ion selective electrodes.

(C)2020 ijrei.com. All rights reserved
\end{abstract}

Keywords: Trimethoprim, HPLC, Spectrophotometric, Analytical Techniques.

\section{Introduction}

Trimethoprim chemically its 5-(3, 4, 5-Trimethoxybenzyl) pyrimidine -2, 4-diamine, is $\mathrm{C} 14 \mathrm{H} 18 \mathrm{~N} 4 \mathrm{O} 3$, representing a molecular weight of $290.3 \mathrm{~g} / \mathrm{mole}$. White or yellowish-white powder, very slightly soluble in water, slightly soluble in ethanol. Dihydrofolate eductase [1]. Few analytical techniques were used for determination trimethoprim which studied Concentration range, correlation coefficient, detection limit, recovery, relative standard deviation, type of column, mobile phase, flow rate, slope, response time and the range of $\mathrm{PH}$ for trimethoprim or sulfamethoxazole. The results of this study were listed in Tables $1,2,3$. In addition for tables $1,2,3$ there were another analytical method for determination of trimethoprim such as: square wave voltammetry [3], Photo-Fenton Oxidation Technology [4], charge transfer complexes formation [5].<smiles>COc1cc(Cc2cnc(N)nc2N)cc(OC)c1OC</smiles>

(a)<smiles>Cc1cc(NS(=O)(=O)c2ccc(N)cc2)no1</smiles>

(b)

Figure 1: Chemical structures of (a) trimethoprim (b) sulfamethoxazole [2]

Corresponding author: Amina M. Abass 
Table 1: Spectrophotometric methods for determination of Trimethoprim

\begin{tabular}{|c|c|c|}
\hline Name of Method & Results & Ref. No \\
\hline Extractive spectrophotometric & $\begin{array}{l}\text { Sample : trimethoprim } \\
\lambda \text { max }=422,418 \mathrm{~nm} \\
\text { Concentration Range }=4.0-24 \text { and } 5.0-25, \mu \mathrm{g} / \mathrm{ml} \\
\mathrm{r}^{2}=0.9969,0.9973 \\
\% \mathrm{Re}=99.95,99.93 \\
\text { Slope }=0.000391,0.000572 \\
\% \mathrm{RSD}=1.600,0.8593\end{array}$ & [6] \\
\hline Simultaneous spectrophotometric & $\begin{array}{l}\text { Sample : trimethoprim-sulphamethoxazole } \\
\lambda_{\max }=520,440 \mathrm{~nm} \\
\text { Beer's law limits }=7.5-60,2-10 \mu \mathrm{g} / \mathrm{ml} \\
\text { Limit of detection }=2.69,0.589 \mu \mathrm{g} / \mathrm{ml} \\
\text { Slope }=0.0048 \pm 7.5 \times 10^{-5,} 0.024 \pm 2.627 \times 10^{-3} \\
\mathrm{r}^{2}=0.9989,0.9992\end{array}$ & [7] \\
\hline Spectrophotometric & $\begin{array}{l}\text { Sample: Sulfamethoxazole , trimethoprim } \\
\lambda \max =237,257,288 \mathrm{~nm} \\
\text { Concentration Range }=2.0-11.0,3.0-18.0 \mu \mathrm{g} / \mathrm{Ml}\end{array}$ & [8] \\
\hline First-Order Derivative Spectroscopy & $\begin{array}{l}\text { Sample : trimethoprim, sulphamethoxazole } \\
\lambda_{\max }=247.8,257.9 \mathrm{~nm} \\
\text { Concentration Range }=10-50,250-350 \mu \mathrm{g} / \mathrm{ml}\end{array}$ & [2] \\
\hline UV-VIS Spectrophotometric-Colorimetric & $\begin{array}{l}\text { Sample : trimethoprim } \\
\text { Concentration Range }=1-35,20-90 \mu \mathrm{g} / \mathrm{ml} \\
\mathrm{r}^{2}=0.9976,0.9981 \\
\mathrm{LOD}=2.724 .90 \mu \mathrm{g} / \mathrm{ml} \\
\% \text { Average recovery }=99.07 \pm 1.46,99.86 \pm 2.35\end{array}$ & [9] \\
\hline Spectrophotometric & $\begin{array}{l}\text { Sample sulphamethoxazole } \\
\lambda_{\max }=460 \mathrm{~nm} \\
\text { Concentration Range }=5-50 \mu \mathrm{g} / \mathrm{ml} \\
\text { Molar absorptivity }=6.7878 \times 104-7.0918 \times 104 \mathrm{~L} \cdot \mathrm{mol}^{-1} \cdot \mathrm{cm}^{-1} \\
\text { Limit of detection }=0.3755-0.3594 \mu \mathrm{g} / \mathrm{ml}\end{array}$ & {$[10]$} \\
\hline UV Spectrophotometry & $\begin{array}{l}\text { Sample : trimethoprim-sulphamethoxazole } \\
\lambda_{\max }=265,289 \mathrm{~nm} \\
\text { Concentration Range }=2-9,9.08-41 \mu \mathrm{g} / \mathrm{ml} \\
\% \text { Recovery }=98.20-99.25 \\
\% \mathrm{RSD}=0.440,0.569\end{array}$ & [11] \\
\hline First-order derivative spectrophotometric & 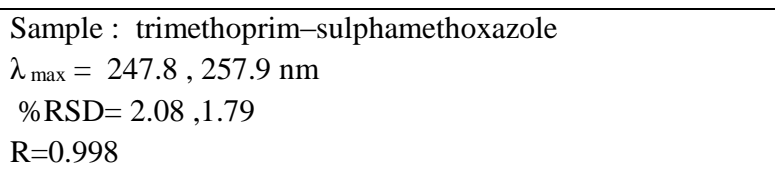 & [12] \\
\hline Spectrofluorometry & $\begin{array}{l}\text { Sample : trimethoprim-sulphamethoxazole } \\
\lambda_{\max }=295,330 \mathrm{~nm} \\
\text { Concentration Range }=0.5 \text { to } 40,1-400 \mu \mathrm{g} / \mathrm{ml} \\
\mathrm{R}=>0.99\end{array}$ & [13] \\
\hline Derivative Spectrophotometry & $\begin{array}{l}\text { Sample : trimethoprim-sulphamethoxazole } \\
\lambda_{\max }=257.8,251.5 \mathrm{~nm} \\
\mathrm{R}=0.9992,0.9995 \\
\text { Concentration } \text { Range }=2.00 \text { to } 25.00 \mathrm{mg} / \mathrm{ml} \\
\mathrm{LOD}=0.36,0.382 \mathrm{mg} / \mathrm{ml} \\
\% \mathrm{Re}=97.23,102.13\end{array}$ & {$[14]$} \\
\hline
\end{tabular}


Table 2: HPLC for determination of Trimethoprim

\begin{tabular}{|c|c|c|c|c|c|c|c|c|}
\hline Method & Column & Mobil Phase & Elution & Flow Rate & Results & $\mathrm{t}_{\mathrm{R}}$ & $\lambda(\mathrm{nm})$ & Ref. \\
\hline Simultaneous HPLC & $\begin{array}{l}\text { C18 column }(5 \mathrm{~m}, 150 \text {, } \\
4.6 \mathrm{~mm})\end{array}$ & $\begin{array}{l}\text { acetonitrile, } 0.5 \% \text { triethylamine in } 1 \% \\
\text { acetic acid, } \mathrm{pH} 3\end{array}$ & $(18: 82, \mathrm{v} / \mathrm{v})$ & $1.5 \mathrm{ml} / \mathrm{min}$ & $\begin{array}{l}\text { Conc. Range }=35-101,102-306 \mu \mathrm{g} / \mathrm{ml} \text {, } \\
\mathrm{R}=0.9980,0.9998 \\
\% \mathrm{Re}=99.7 \pm 0.92 \\
\% \mathrm{RSD}=0.05-8.94\end{array}$ & $\begin{array}{l}3.2,16 \\
\min \end{array}$ & 271 & {$[15]$} \\
\hline HPLC-DAD & RP-18 & $\begin{array}{l}32 \mathrm{ml} \\
\text { methanol-dichloromethane }\end{array}$ & $70: 30, v / v)$ & $1 \mathrm{ml} / \mathrm{min}$ & $\begin{array}{l}\text { Conc. Range }=22.0-54.0,21.3-32.7 \\
\text { ng/L }\end{array}$ & - & - & {$[16]$} \\
\hline $\begin{array}{l}\text { Liquid } \\
\text { Chromatography }\end{array}$ & $\mathrm{C} 18$ & $\begin{array}{l}0.1 \% \text { formic acid in water and } \\
\text { acetonitrile }\end{array}$ & $\begin{array}{l}\text { isocratic } \\
\text { elution } \\
\text { mode }\end{array}$ & & $\begin{array}{l}\text { Conc. Range }=5-250 \mathrm{ng} \cdot \mathrm{g}^{-1} \\
\mathrm{LOD}=1 \mathrm{ng} \cdot \mathrm{g}^{-1} \\
\% \mathrm{R}=0.9984\end{array}$ & & & {$[17]$} \\
\hline RP-LC & $\begin{array}{l}\text { C18 }(150 \times 4.6 \mathrm{~mm}, 5 \\
\mathrm{mm}) .\end{array}$ & water, $\mathrm{pH} 3.5$, and methanol & $(60: 40, \mathrm{v} / \mathrm{v})$ & $1.0 \mathrm{ml} / \mathrm{min}$ & $\begin{array}{l}\text { Conc. Range }=5-70,1-30 \mathrm{mg} \mathrm{mL}^{-1} \\
\mu \mathrm{g} / \mathrm{ml}, \mathrm{R}=\geq 0.99\end{array}$ & - & $\begin{array}{l}213 \text { and } \\
230\end{array}$ & {$[18]$} \\
\hline HPLC & - & $\begin{array}{l}\text { Phosphate buffer } 0.1 \mathrm{M} \text {, acetonitrile } \\
\text { and methanol }\end{array}$ & $(65: 20: 15)$ & $1.0 \mathrm{ml} / \mathrm{min}$ & $\begin{array}{l}\text { Conc. Range }=0.25-5,5-100 \mu \mathrm{g} / \mathrm{ml} \\
\mathrm{R}=0.9998,0.9996 \\
\% \mathrm{Re}=92.23,96.85 \\
\mathrm{DOL}=0.2,3 \mu \mathrm{g} / \mathrm{ml}\end{array}$ & - & 225 & [19] \\
\hline RP-HPLC & $\begin{array}{l}\text { C18 (250mm x } 4.6 \mathrm{~mm}, \\
5 \mu \mathrm{m}) .\end{array}$ & Triethylamine:Acetonitrile & $(30: 70)$ & $1.0 \mathrm{ml} / \mathrm{min}$ & $\begin{array}{l}\mathrm{Re}=100.23,99.30 \\
\% \mathrm{RSD}=0.6,0.4\end{array}$ & $\begin{array}{l}2.688, \\
4.388\end{array}$ & 260 & {$[20]$} \\
\hline $\begin{array}{l}\text { High Performance } \\
\text { Liquid } \\
\text { Chromatography }\end{array}$ & $\begin{array}{l}\text { C18 analytical column } \\
\text { (stainless steel, } 25 \mathrm{~cm} \text {, } \\
4.6 \mathrm{~mm} \text { ) }\end{array}$ & $\begin{array}{l}0.025 \mathrm{M} \text { sodium phosphate as } \\
\text { aqueous phase, acetonitrile , } 0.4 \% \\
\text { triethylamine as organic phase }\end{array}$ & $(80 / 20)$ & $1.2 \mathrm{ml} / \mathrm{min}$ & $\mathrm{R}=0.986,0.949$ & - & 260 & {$[21]$} \\
\hline HPLC & $\begin{array}{l}\mathrm{C} 18(250 \mathrm{~mm} \times 4.6 \\
\text { mm X } 5 \mu \mathrm{m} \text { particle } \\
\text { size })\end{array}$ & $\begin{array}{l}20 \% 0.05 \mathrm{M} \text { potassium dihydrogen } \\
\text { orthophosphate, } \mathrm{pH} 3.5-80 \% \\
\text { acetonitrile }\end{array}$ & - & $1.5 \mathrm{ml} / \mathrm{min}$ & $\begin{array}{l}\text { Conc. Range }=1-18,1-16 \mu \mathrm{g} / \mathrm{ml} \mathrm{R}= \\
0.9998,0.9996 \% \mathrm{Re}=100.02 \pm 0.869 \\
100.51 \pm 0.978\end{array}$ & - & 225 & {$[22]$} \\
\hline RP-HPLC & C18 Phenomenex & $\begin{array}{l}\text { acetonitrile: potassium dihydrogen } \\
\text { orthophosphate buffer, } \mathrm{pH} \text { adjusted to } \\
3.8 \text { using orthophosphoric acid }\end{array}$ & $(20: 80)$ & $1 \mathrm{ml} / \mathrm{min}$ & $\begin{array}{l}\text { Conc. Range }=2-10,1-5 \mu \mathrm{g} / \mathrm{ml} \\
\mathrm{R}=0.999, \mathrm{LOD}=0.0024,0.0009 \mu \mathrm{g} / \mathrm{ml} \\
\text { and } 0.0072 \mu \mathrm{g} / \mathrm{ml}, 0.0028 \mu \mathrm{g} / \mathrm{ml}\end{array}$ & $\begin{array}{l}5.2 \\
2.4\end{array}$ & 248 & {$[23]$} \\
\hline RP-HPLC & $\mathrm{C} 18(4.6,150 \mathrm{~mm}, 4 \mathrm{~m})$ & $\begin{array}{l}30 \mathrm{mM} \text { sodium phosphate (pH 5.8), } \\
\text { acetonitrile, and } 0.05 \% \text { triethylamine }\end{array}$ & $\begin{array}{l}(83: 17: 0.05 \\
\text {,) v/v }\end{array}$ & $1.2 \mathrm{ml} / \mathrm{min}$ & $\begin{array}{l}\text { Conc. Range }=0.10-6.0,1.0-70 \mu \mathrm{g} / \mathrm{ml}, \\
\mathrm{R}=0.999, \\
\mathrm{LOD}=0.0024,0.0009 \mu \mathrm{g} / \mathrm{ml} \text { and } 0.0072 \\
\mu \mathrm{g} / \mathrm{ml}, 0.0028 \mu \mathrm{g} / \mathrm{ml}\end{array}$ & & 235 & {$[24]$} \\
\hline
\end{tabular}

Table 3:Ion-Selective Electrodes for Determination of Trimethoprim

\begin{tabular}{|c|c|c|c|c|c|c|c|c|}
\hline $\begin{array}{l}\text { Type of Ion -pair for } \\
\text { Electrodes }\end{array}$ & $\begin{array}{c}\text { Slope } \\
\mathrm{mV} / \text { decade }\end{array}$ & Conc. Range & Detection Limit & $\mathrm{R}$ & $\begin{array}{l}\text { Response } \\
\text { Time }\end{array}$ & $\mathrm{PH}$ & Life Time & Ref. \\
\hline $\begin{array}{l}\text { Trimethoprim- } \\
\text { Molybdophsophoric acid }\end{array}$ & $\begin{array}{l}58.61,58.41, \\
15.30\end{array}$ & $\begin{array}{l}1.2 \times 10^{-5}-1.0 \times 10^{-2} \text { and } 6.1 \times 10^{-5}-1.0 \times 10^{-2} \\
\text { and } 2.5 \times 10^{-5}-1.0 \times 10^{-2} \mathrm{~mole} / \mathrm{L}\end{array}$ & $\begin{array}{c}2.5 \times 10^{-6}, 6.3 \times 10^{-6}, \\
5.9 \times 10^{-6} \mathrm{~mole} / \mathrm{L}\end{array}$ & $\begin{array}{c}0.9996,0.9996 \\
0.9997\end{array}$ & - & $\begin{array}{l}3.0-8.0,3.0-6.5 \\
7.0-8.5 \\
\end{array}$ & $45,1,2$ days & {$[25]$} \\
\hline $\begin{array}{l}\text { Trimethoprimium- } \\
\text { phosphomolybdata }\end{array}$ & $56 \cdot 5$ & $2.3 \times 10^{-6}-10^{-2} \mathrm{~mole} / \mathrm{L}$ & - & $0 \cdot 00091$ & - & $1 \cdot 6-6 \cdot 2$ & 24 hours & [26] \\
\hline $\begin{array}{l}\text { Trimethoprim- methyl } \\
\text { orange }\end{array}$ & $57.31,42.00$ & $6.0 \times 10^{-6}-1.0 \times 10^{-2}$ & $3.0 \times 10^{-6}$ & $0.9903,0.9990$ & - & $\begin{array}{c}2.0-5.5,1.5-4.5,3.0-4.5 \\
\text { and, } 4.5-5.2,3.0- \\
4.0,1.0-3.5\end{array}$ & 27,3 days & {$[27]$} \\
\hline
\end{tabular}




\section{Conclusion}

In this review, a theoretical study of more analytical technique used for evaluation trimethoprim were listed in Table 1, 2 and 3. From these tables founded the best method was high performance liquid chromatography, also according to the United States Pharmacopeia (USP) [3], the official method for the simultaneous analysis of sulfamethoxazole and trimethoprim in pharmaceutical formulations implicates to use High Performance Liquid Chromatography (HPLC).This method was gave a wide concentration range determined in $\mathrm{ng} / \mathrm{ml}$ and $\mu \mathrm{g} / \mathrm{ml}$, with low detection limit and the most solvent used were acetonitrile and methanol. In the other hand, spectrophotometric and ion selective electrodes were successfully applied to the determination of trimethoprim and sulfamethoxazole in tablet dosage forms with accuracies comparable to the official BP method. These methods were very easy to use and easy to apply and besides very cheap to quality control and routine analysis of two active veterinary compounds in commercial samples.

\section{References}

[1] British pharmacopoeia 2013, Version 17 Copyright by. London, (2012).

[2] Medina J.R., Miranda M., Hurtado M.,Domínguez Ramirez A.M.,RuizSegura J.C.," Simultaneous Determination of Trimethoprim and Sulfamethoxazole in Immediate-Release Oral Dosage Forms By First-Order Derivative Spectroscopy: Application Dissolution Studies", Int J Pharm Pharm Sci, Vol 5, Suppl 4,pp. 505-510.

[3] Calaca G.N.,Pessoa Ch.A.,Wohnrath K.,Nagata N.,"Suimultaneous Determination of Sulfamethoxazole and Rtimethoprim in Pharmaceutical Formulations by Square Wave Voltammetry", International Journal of Pharmacy and Pharmaceutical Sciences, 6(9),2014.

[4] Azar Bagheri A., khomami S.R.," Determination of Trimethoprim Based on Charge-Transfer Complexes Formation", Journal of Applied Chemical Research, 7, 3,2013,pp. 25-33.

[5] Wang Q., Pang W., MaoY. , Sun Q. , Zhang P., Qiang Ke Q., Yu H., Chuanjun Dai Ch., Zhao M.," Study of the Degradation of Trimethoprim Using Photo-Fenton Oxidation Technology", Water 2019, 11, 207.

[6] Reddy S.P., Vardhan S.V.M., Krishna K.B., Rambabu C.," Extractive spectrophotometric determination of trimethoprim in pharmaceutical formulations", ACAIJ, 14(11), 2014.

[7] Adegoke O.A., Babalola Ch.P., Kotila O.A., Obuebhor O.," Simultaneous spectrophotometric determination of trimethoprim and sulphamethoxazole following charge-transfer complexation with chloranilic acid", Arabian Journal of Chemistry 10,2017, S3848-S3860.

[8] Hişmioğulları S.E., Yarsan E.," Spectrophotometric Determination and Stability Studies of Sulfamethoxazole and Trimethoprim in Oral Suspension by Classical Least Square Calibration Method", Hacettepe University Journal of the Faculty of Pharmacy, 29(2), 2009, pp. 95-104.

[9] Stojković G., Dimitrieska-Stojković E., Marija Soklevska M., Romel Velev R.," Optimization, Validation and Application of UV-VIS Spectrophotometric- Colorimetric Methods for Determination of Trimethoprim in Different Medicinal Products", Mac Vet Rev, 39 (1), 2016, pp. 65-76.

[10] Khalaf H.S., Al-Haidari A.M.A., Dikran S.B., Alaa K. Mohammed A.K.," Spectrophotometric Determination of Sulfamethoxazole in Pure and Pharmaceutical Preparations Based on Condensation Reaction Method" Journal of Babylon University/Pure and Applied Sciences, 2(25),2017.

[11] Venipokala R.,Kumari K.,Bollikola H.B.," UV Spectrophotometry Method Development and Validation of Sulfadiazine and Trimethoprim in Combined Dosage Form", Int J Pharm Pharm Sci, 10(1),2018, pp. 103-107.
[12] Medina R., Miranda M., Hurtado M., Domínguez- Ramírez A.M., Octavio Reyes O., Ruiz-Segura J.C.," In vitro Evaluation of Trimethoprim and Sulfamethoxazole from Fixed-Dose Combination Generic Drugs using Spectrophotometry: Comparison of Flow-Through Cell and USP Paddle Methods", Trop J Pharm Res, November , 14(11),2015,pp. 2061-2069.

[13] Lichtenwalner D. M., Suh B., Lorber B., SugarA.M." Rapid Assay for Determination of Trimethoprim and Sulfamethoxazole Levels in Serum by Spectrofluorometry", antimicrobial agents and chemotherapy, 1979, pp. 579-583.

[14] Al-Saidi K.H., Yonis M.S.," Simultaneous Determination of Sulphamethoxazole and Trimethoprim in Binary Mixtures and in Tablet Using Derivative Spectrophotometry", Journal of Al-Nahrain University,18(1),2015,pp.46-54.

[15] Lakkanatinaporn P., Matayatsuk Ch.," Simultaneous HPLC method for determination of sodium trimethoprim phenylpropanol disulphonate and sodium sulfaquinoxaline in veterinary drugs ", Songklanakarin J. Sci. Technol.,26(6),2004.

[16] Madureira T.V., Rocha M.J.,Cass Q.B.,Maria Elizabeth Tiritan M.E.," Development and Optimization of a HPLC-DAD Method for the Determination of Diverse Pharmaceuticals in Estuarine SurfaceWaters", Journal of Chromatographic Science, 48, 2010.

[17] Nunes K.S.D., Assalin M.R.,Vallim J.H., Jonsson C.M., Queiroz S.C.N., Reyes F.G.R.," Multiresidue Method for Quantification of Sulfonamides and Trimethoprim in Tilapia Fillet by Liquid Chromatography Coupled to Quadrupole Time-of-Flight Mass Spectrometry Using QuEChERS for Sample Preparation", Journal of Analytical Methods in Chemistry, Volume 2018, 10 pages.

[18] Tahan G.P., Machado S.C., Malaguti E.C., Maia P.P., Rath S., Isarita Martins I.," RP-LC method for simultaneous determination of sulfamethoxazole and trimethoprim content in veterinary drugs", Original research publication in all aspects of Chemistry, $40,2015$.

[19] López A.T., Olguín H.J. , Lares-Asseff I., González F.R., Medina R.A., Guillé G.P., Jimenez F.T.," A Reliable Method to Quantify Trimethoprim and Sulfamethoxazole in Plasma of Children by HPLC with Application in Pharmacokinetic HPLC with Application in Pharmacokinetic HPLC with Application in Pharmacokinetic Studies", American Journal of Analytical Chemistry, 10, 2019,pp.247-253.

[20] Gurumurthy T.,Monika M.,Ashwini V.," Development and validation RPHPLC method for simultaneous estimation of Sulfamethoxazole and Trimethoprim",Indian Journal of Research in Pharmacy and Biotechnology, 5(3),2017,pp. 235-238.

[21] Rezaee A., Nejad Q.B., Kebriaeezadeh A.," Simultaneous Analysis of Trimethoprim and Sulphamethoxazole Drug Combinations in Dosage Forms by High Performance Liquid Chromatography", Iranian Biomedical Journal 4 (2 \& 3), 2000, pp. 75-78.

[22] El-Abasawy N.M., Attia K.A.M., Abo-Serie A.A., Said R.A., Almrasy A.A.," HPLC Method for Determination of Binary Mixture of Phenazopyridine Hydrochlride and Trimethoprim in Bulk and Pharmaceutical Preparation", World Journal of Pharmacy and Pharmaceutical Sciences ,7(3), 2018.

[23] Rajapandi R., Resmi V. R. , Venkateshan N. , Babu G.," Development and validation of RP-HPLC method for the simultaneous estimation of sulfadoxine and trimethoprim in bulk and pharmaceutical dosage forms", Der Pharmacia Lettre, 8 (19), 2016,pp.316-323.

[24] Alvi S.N., Hammami M.M.," Simultaneous determination of sulfamethoxazole and trimethoprim in human plasma by RP-HPLC", ACAIJ, 7(8), 2008.

[25] Abass A.M., Ahmed A.,"Synthesis and Application of Trimethoprim Selective Electrodes", RJLBPCS 3(2), 2017, pp.146-156.

[26] Aboudan M., Issa Y.M.,Shoukry A.F.," New plastic membrane ion-selective electrode for determination of trimethoprim", Journal of Chemical Technology \&amp; Biotechnology,61(1),1994.

[27] Abrahem S.A.,Abass A.M.,Ahmed A.," Trimethoprim Determination with Drug-Selective Electrodes", Asian J Pharm Clin Res, 12(6), 2019,pp. 83-87.

Cite this article as: Amina M. Abass, Sahar Alabdullah, Huda ghalib Salman, Determination of trimethoprim by various analytical techniques-A review, International Journal of Research in Engineering and Innovation Vol-4, Issue-1 (2020), 1-4. http://doi.org/10.36037/IJREI.2020.4101 